\title{
Transformational leadership in the South African public service after the April 2009 national elections
}

\author{
Authors: \\ Manasseh M. Mokgolo ${ }^{1}$ \\ Patricia Mokgolo ${ }^{2}$ \\ Mike Modiba ${ }^{3}$

\section{Affiliations:} \\ ${ }^{1}$ Department of Human \\ Resources Management, \\ University of South Africa, \\ South Africa \\ ${ }^{2}$ Learning and Development \\ Unit, Tromso Management \\ Consultants CC, Boyne, \\ South Africa \\ ${ }^{3}$ Tromso Management \\ Consultants CC, Boyne, \\ South Africa \\ Correspondence to: \\ Manasseh Mokgolo \\ Email: \\ mokgomm@unisa.ac.za \\ Postal address: \\ PO Box 392, University of \\ South Africa, Pretoria 0003, \\ South Africa

\section{Dates:} \\ Received: 13 Oct. 2010 \\ Accepted: 28 Sept. 2011 \\ Published: 23 Apr. 2012 \\ How to cite this article: \\ Mokgolo, M.M., Mokgolo, \\ P., \& Modiba, M. (2012). \\ Transformational leadership \\ in the South African public \\ service after the April \\ 2009 national elections. SA \\ Journal of Human Resource \\ Management/SA Tydskrif vir \\ Menslikehulpbronbestuur, \\ 10(1), Art. \#334, 9 pages. \\ http://dx.doi.org/10.4102/ \\ sajhrm.v10i1.334
}

(C) 2012. The Authors. Licensee: AOSIS OpenJournals. This work is licensed under the Creative Commons Attribution License.
Orientation: The implementation of transformational leadership in public services after national elections has been well recorded in other parts of the world. However, this is not the case in South Africa.

Research purpose: The purpose of the study is to determine whether transformational leadership has a beneficial relationship with subordinate leadership acceptance, job performance and job satisfaction.

Motivation for the study: Leadership is a critical issue that the public sector needs to address in order to survive and succeed in today's unstable environment. According to Groenewald and Ashfield (2008), transformational leadership could reduce the effects of uncertainty and change that comes with new leaders and help employees to achieve their objectives.

Research design, approach and method: The sample comprised 1050 full-time employees in the public sector based in head offices. The measuring instruments included the Multifactor Leadership Questionnaire (MLQ), the Leadership Acceptance Scale (LAS), the Job Satisfaction Survey (JSS) and the Job Performance Survey (JPS).

Main findings: Transformational leadership had a positive correlation with subordinate leadership acceptance, performance and job satisfaction.

Practical/managerial implications: Managers can train public sector leaders to be transformational leaders because of the adverse effect lack of transformation can have on employees' attitudes in areas like satisfaction, performance and commitment.

Contribution/value-add: This study makes an important contribution to our understanding of transformational leadership processes and to how the public service can improve its practices in order to render quality service to South Africans.

\section{Introduction}

\section{Background to the study}

South African public service leadership is a sensitive matter on the agenda of interest groups and societies, to mention a few, today. The United Nations Development Programme (2003, p. 2) highlighted that 'for the public sector organisations to survive and succeed in today's unstable ever changing environment they need to address leadership'. Furthermore, the United Nations Development Programme (2003) emphasises that the public service needs a corps of people who, whilst operating within the framework of the rule of law, are able to apply transformational leadership skills when tackling extraordinarily difficult challenges.

Bass (1985, 1998); Bass and Avolio (1994); Nemanich and Keller (2007); Waldman, Javidan and Varella (2004) define transformational leadership as a relationship between a leader and followers based on a set of leadership behaviours that subordinates see as showing idealised influence, motivational inspiration, intellectual stimulation and consideration for people.

In addition, line managers or leaders are key sources of influence on leadership acceptance, performance and job satisfaction. Employees who work in changing situations may have a more positive, open-minded approach to the change of leaders and develop a more accepting attitude.

Groenewald and Ashfield (2008) argue that transformational leaders could reduce the effects of uncertainty and change that comes with new leaders and help employees to achieve their objectives. Bass and Avolio (1994) supported this idea. They state that transformational leaders could raise subordinate performance to an acceptable standard.

Researchers like Haslam and Platow, 2001;Hogg and Terry, 2001; and Hogg and Van Knippenberg, 2003 assert that a shift from the individual towards the social (group) level of identity is a 
step toward successful leadership transformation. Van Knippenberg and Hogg (2003) and Van Dick (2004) argue that the members of high salience groups, with which people identify strongly, significantly affect the efficacy of their leaders according to how prototypical of them the members see them to be.

\section{The research problem}

National elections represent a significant strategic renewal for government leaders. However, they also pose significant challenges to the effectiveness of their leadership. According to Nemanich and Keller (2007):

successful management of employees' attitudes after national elections is vital because employees can choose to leave the services or remain, hold onto critical operational knowledge or share it, and raise their productivity level or become distracted by new leadership. Further, stress that leadership transformation and redeployment of employees can cause social identity issues that can lead to frustration and anger about uneven performance and reduced job satisfaction. (p. 49)

Ernst and Vitt, 2000; Hogg and Terry, 2000; and Nygaard and Dahlstrom, 2002 maintain that these leadership issues can cause an exodus of talent, tardiness, absenteeism, lower productivity, reduced customer satisfaction, less innovation and, ultimately, reduced economic benefits. Therefore, it is vital that managers become transformational leaders because leader effectiveness determines the success levels of organisations.

The transformational leadership literature reminds us that a wide range of factors affects employees. Their leaders, who hope to initiate change in departments and generate follower acceptance, face a daunting task (Kavanagh \& Ashkanasy, 2006; Michela \& Burke, 2000). Early research that built on the 'great man' theory of leadership (Judge, Bono, Ilies \& Gerhardt, 2002) found that, for leaders to be effective, they must behave differently in different situations. Transformational leadership positively affects a wide range of individual and organisational outcomes in a variety of contexts, including business (Jung, Chow \& Wu, 2003), the public sector (Rafferty \& Griffin, 2004) and education (Koh, Steers \& Terborg, 1995).

\section{Research objectives}

Recent reviews (Balogun, 2003; Harris \& Moran, 2000) of research into government or public service leadership transformation after national elections show that few studies in South Africa have examined the effect of transformational leadership on subordinate leadership acceptance, job performance and job satisfaction. Therefore, the present study has attempted to answer the research question of whether transformational leadership has a beneficial relationship with subordinate leadership acceptance, job performance and job satisfaction.

The main objectives of this paper are:

- to obtain information on how transformational leadership variables relate to subordinate leadership acceptance, job satisfaction and performance
- to provide policy-makers with useful recommendations on how to improve and develop best transformational leadership practices.

\section{Trends from the research literature}

\section{Transformational leadership and contextual antecedents}

Transformational leadership theory postulates that transformational leadership emerges more strongly and effectively in situations of crisis or uncertainty, like those that occur after elections (Bass, 1990; Shamir, House \& Arthur, 1993; Yukl \& Howell, 1999).

According to Bass, Avolio, Jung and Berson (2003) as well as Vera and Crossan (2004), transformational leaders help subordinates to unlearn past routines, develop creative solutions to ambiguous problems and respond appropriately to new environments.

Waldman, Ramirez, House and Puranam (2001) argue that charismatic leadership influences the performance of organisations in an environment of uncertainty, but not in more stable situations. Pillai and Meindl (1998) also found that, in demanding circumstances, transformational leadership behaviour tended not to emerge. In a study that Covin, Kolenko, Sightler and Tudor (1997) conducted, charismatic leadership behaviours had a positive relationship with employee satisfaction.

Therefore, transformational leadership is 'a relationship between a leader and followers based on a set of leader behaviours perceived by subordinates as exhibiting idealised influence, motivational inspiration, intellectual stimulation, and individual consideration' (Bass, 1985, 1998; Bass \& Avolio, 1994, p. 88).

According to Bass (1998) individualised consideration makes employees feel that their organisations value them and their need to understand and resolve their personal uncertainties. Transformational leaders make subordinates feel that they have a calling to work toward a valuable purpose, like building new and larger entities. The effect of these transformational behaviours is that employees will be more satisfied with their jobs because they believe that they are doing important work for leaders who value their contributions.

\section{Leadership acceptance}

Leadership acceptance is the extent to which subordinates have a positive attitude to their appointed leaders and perceive the changes as beneficial (Bass \& Avolio, 1994). According to Marks and Mirvis (1992), leadership acceptance is an important organisational outcome because subordinates, who are more satisfied with the organisational change strategy (like new management styles), are likely to adjust more quickly to the new culture and strategies that the new leaders are trying to implement. In addition, they argue that resistance to the new leaders is an underlying cause of unproductive behaviours that range from reduced productivity to sabotage. 
Employees enter their new jobs with their own set of expectations based upon their previous experience. These expectations place meaning, motivation and cause-effect relationships in order. According to Drazin, Glynn and Kazanjian (1999), they share commonalities in these expectations with co-workers from the same previous leaders, but not with co-workers from the new leaders. Employees' pre-existing expectations may also overlap very little and even conflict with new their leaders' expectations, which represent the reality of the new leaders. In addition, Robbins, Odendaal and Roodt (2002, p. 73) state that 'this cognitive dissonance (incompatibility) is aroused by the uncertainty and disruptive change process, increases the influence and importance of leader behaviours'.

When leaders change, employees become aware that the measuring tools for performance and loyalty have changed suddenly. This threat to the traditional values and lifestyles of their organisations leaves employees in a state of defensiveness that low levels of trust and cultural shock accentuate. McKendall (1993) also suggested that:

employee reactions pass through four stages: (1) disbelief and denial, (2) anger, then rage and resentment, (3) emotional bargaining beginning in anger and ending in depression, and finally (4) acceptance. Unless these different stages are recognised and dealt with astutely, employees will have difficulty reaching the acceptance stage, and the risk of leadership integration failure is increased significantly. (p. 100)

For subordinates to be satisfied with their new leaders, they need to be able to understand the need for social services and believe that this is worthy of the disruption the new leaders may cause. They need to be able to relate to the new vision for the future at national, provincial and municipal level and find it to be a desirable objective. The skills of transformational leaders facilitate this process by explaining the vision and socially constructing common frames that form the groundwork for building consensus. The skills of leaders at communicating a vision to employees, and inspiring support for it, are the basis for building employee understanding of organisations' reasons for change. In support of these arguments, Robbins et al. (2002), and Nemanich and Keller (2007) have found that charismatic leadership has a positive relationship with leadership acceptance.

During times of leadership change, it is important that the leaders of organisations create an atmosphere of psychological safety for all employees to engage in the new behaviours, and they need to be involved in order to verify for themselves the validity of the new beliefs and values.

According to Nemanich and Keller (2007), transformational leadership is essentially a process of social influence in which employees want to feel included, supported and reinforced. Van Dick (2004), Van Knippenberg and Hogg (2003) maintain that relations between employees and their leaders will affect perceived leader effectiveness. Therefore, understanding these relations needs to include issues about employees' self-concepts. However, many peripheral aspects, like organisational culture and leadership practices, may be constraining factors that will affect employees and their perceptions of their leaders.

Transformational leaders use idealised influence to empower followers, thereby raising their tolerance for uncertainty and their ability to adapt to new, changing conditions. According to Maitlis (2005):

the powerful communication skills associated with idealised influence can be used in formal and informal meetings with subordinates to expand leaders' abilities to help employees understand the benefits of new leadership. (p. 22)

Vera and Crossan (2004) further emphasise that:

through intellectual stimulation, leaders encourage subordinates to question the universality of previous cognitive frames, opening the door for new frames to develop. By considering each subordinate as an individual, transformational leaders can provide support through the change process by facilitating social reconstruction to bring more uniform interpretations to people with separate experience bases. (p. 222)

The researchers formulated hypothesis 1 using the preceding literature:

- Hypothesis 1: Transformational leadership has a positive relationship with subordinates' leadership acceptance.

\section{Job performance}

Job performance, broadly speaking:

encompasses both what employees do and how well they perform their job, the initiative they take, their resourcefulness in solving problems, the extent to which they completes tasks, the way in which they use their available resources as well as the time and energy they spend on tasks. (Mokgolo, 2008, p. 245)

Transformational leaders inspire followers to perform beyond normal expectations. For example, transformational leadership positively affected the performance of teams in a longitudinal study that Keller (2006) conducted and of subordinates in a cross-sectional study that Whittington, Goodwin and Murray (2004) performed. These studies found that transformational leadership had a direct effect, at all levels in the hierarchy, on the performance of followers.

In addition, by building employees' identification with the new leaders, transformational leaders motivate employees to engage in organisational citizenship (Bono \& Judge, 2003; Shamir et al., 1993) for the good of their organisations. By setting an example of individualised consideration, transformational leaders model positive interpersonal behaviours that reduce conflict and improve productivity in the workplace.

Bass (1985) developed a model of situational antecedents for transformational leadership and emphasised the importance of contextual antecedents in later work (Bass, 1998; Bass et al., 2003). In his model, transformational leadership is particularly effective in changing environments as well as during times of uncertainty and distress (Bass, 1998; House \& Aditya, 1997; Waldman et al., 2001; Yukl \& Howell, 1999). Transformational leaders: 
are essentially change agents; they visualise a future different to that of the status quo and inspire subordinates to work with them to achieve the future goals and objectives of the public service. (Vera \& Crossan, 2004, p. 224)

After national elections, transformational leadership behaviours play a critical role in helping subordinates to accept that a better future lies in integrating public service departments or units. In addition, Bass et al., (2003) state that, by inspiring employees to work toward that future, transformational leaders motivate employees to maintain their satisfaction and improve performance despite their uncertainty and anxiety about integrating.

These studies helped the researchers to formulate their second hypothesis:

- Hypotheisis 2: Transformational leadership has a positive relationship with subordinate job performance.

\section{Job satisfaction}

Because job satisfaction is a widely researched and complex phenomenon, it follows that there are many definitions of the concept. According to Lumley, Coetzee, Tladinyane and Ferreira (2011), job satisfaction is:

an individual's overall feeling about their job and their attitudes towards various aspects or facets of their job, as well as an attitude and perception that can influence the degree of fit between the individual and the organisation. (p. 101)

Robbins (1993) also stated that people with high job satisfaction seem to have generally positive attitudes whilst those who are dissatisfied appear to have generally negative attitudes to their jobs.

Spector (1997), cited in Lumley et al. (2011), explains:

that for researchers to understand these attitudes, they need to understand the complex and interrelated facets of job satisfaction, namely pay, promotion, supervision, benefits, contingent rewards, operating procedures, co-workers, nature of the work and communication. (p. 102)

Research shows that job satisfaction does not occur in isolation because it depends on organisational variables like structure, size, pay, working conditions and leadership, which all characterise the climate of organisations (Sempane, Rieger \& Roodt, 2002).

According to Rothmann and Coetzer (2002, p. 30), job satisfaction amongst employees 'is an indicator of organisational effectiveness, and is influenced by organisational and personal factors'. Most employers realise that the optimal functioning of their organisations depends partly on the level of job satisfaction of their employees. Therefore, the statement that 'happy employees are productive employees' (Saari \& Judge, 2004) applies. Rothmann and Coetzer (2002) also emphasise that employee job satisfaction is very important and, for employee performance to improve, organisations need employees' full commitment at all levels.
Therefore, leadership affects employees' job satisfaction greatly and can cause employees to resign, to become tardy in productivity or to decrease their performance. It is also clear that situational appraisals, which will reflect employees' cognitive evaluations of how situations or events will affect their levels of wellbeing, influence their reactions to changes in leaders. Some employees experience fewer negative effects and are more accepting. Those most affected no longer care and are simply trying to survive.

These notes led the researchers to:

- Hypothesis 3: Transformational leadership has a positive relationship with job satisfaction.

\section{Research design Research approach}

The researchers used a quantitative survey design (Shaughnessy \& Zechmeister, 2003) to achieve their research objectives.

\section{Research method}

\section{Research participants}

The participants were middle- and top-level employees from various public sector departments at provincial head offices. The researchers distributed anonymous questionnaires to 1050 employees, which they had to complete themselves, in all the departments. Of these, $66 \%$ were men and $34 \%$ were women. The participants completed 896 questionnaires. This is a return rate of $85 \%$.

The researchers collected their data from employees a year after the elections. Employee survey instruments collected data on employees' perceptions of:

- their managers' transformational leadership behaviours

- their perceptions of their own levels of leadership acceptance, job performance and job satisfaction.

The employee questionnaires included an open-ended invitation to provide comments.

The researchers drew a 30\% systematic random sample using a population list of approximately 3500 public sector employees from all functional categories. The sample excluded employees in departments located outside the head office in each province. The reason was that employees in these departments do not often engage in as broad a range of tasks as employees in head offices do.

\section{Measuring instruments}

The researchers used employee survey instruments to collect data on perceptions of:

- managers' transformational leadership behaviours

- employees' perceptions of their acceptance of leadership

- employees' perceptions of their job performance

- employees' perceptions of their job satisfaction. 
The employee survey questionnaires included an openended invitation to provide comments.

The researchers measured all variables using a five-point response scale. It ranged from 1 (strongly disagree) to 5 (strongly agree). In some cases, the researchers needed to make slight changes to sentence structure.

The transformational leadership questionnaire: The researchers measured transformational leadership using the Multifactor Leadership Questionnaire (MLQ). It comprised 20 items. The researchers selected the items according to how well employees assessed the theoretical constructs the researchers highlighted in the introduction to this article (Bass \& Avolio, 2000).

The MLQ assesses idealised influence, inspirational motivation, intellectual stimulation and individualised consideration. In some cases, the researchers needed to make slight changes to sentence structure. The researchers discuss the transformational leadership questionnaire items below.

For idealised influence, the items the researchers included the extent to which managers encourage employees to be team players, motivate sections to work together to achieve the same goals, develop a team attitude and spirit amongst employees and believe that all employees are crucial to the success of the departments' goals.

For inspirational motivation, the items the researchers included the extent to which managers encourage high standards, talk optimistically, express confidence and speak enthusiastically.

For intellectual stimulation, the items the researchers included the extent to which managers ask questions that make employees think, get employees to rethink the way they do things and challenge employees to think about problems in new ways.

For individualised consideration, the items the researchers included how managers spend their time, the extent to which managers treat employees as individuals, the extent to which managers consider that employees have different strengths and abilities from others and develop employees' strengths. The Cronbach's alpha was .96.

The Leadership Acceptance Scale (LAS): Covin et al. (1997) developed the LAS. The researchers used it to assess and determine employees' perceptions about the leadership transition. The researchers used 13 items and in some cases they had to make slight changes to sentence structure. The LAS assessed the dimensions of responsibility, influence, teamwork, ability, goal setting and self-image as well as the extent to which employees accept change. The Cronbach's alpha was .71.

The Job Satisfaction Survey (JSS): The researchers measured job satisfaction using 12 items from the scale that Spector
(1997) designed. The JSS measured security, working conditions and advancement. Mokgolo (2008) previously tested the JSS on a sample of 231. It yielded a Cronbach's alpha of .88 (Mokgolo, 2008). The Cronbach's alpha for this study was .79.

The Job Performance Survey (JPS): The researchers measured job performance using 12 items from Zammuto, London and Rowland (1982) and Schepers (1994). The researchers used the JPS to measure the accomplishment of objectives and acceptability of interpersonal behaviours. The job performance items included achievement, flexibility and innovation, decision centralisation and social relations. Cronbach's alpha for this study was .76.

\section{Research procedure}

The researchers received ethical clearance and permission to conduct the study from all the provincial departments that agreed to participate in the study. They visited the participants at their workplaces to conduct sessions that would last approximately 40 minutes each, during which they would collect the data. All participants received the questionnaires and covering letters that explained the purpose of the study and ensured confidentiality. The participants indicated their consent to participate by returning the questionnaires.

\section{Statistical analysis}

The researchers chose their data analysis procedures based on their applicability to the correlational nature of the research design. The researchers used descriptive and inferential statistics to analyse the data.

They conducted linear regression analyses to test their research hypotheses. Although they set a cut-off point of $p<.05$, they also considered a practical effect size of $r>.30$ (medium effect, Cohen, 1992) for the correlational analyses so that they could interpret the practical significance of the findings. In terms of the linear regression analyses, they used the value of adjusted $R^{2}$ to determine the proportion of the total variance of the dependent variables (SLA, JPS and JSS) that the independent variable (MLQ) explained. For the purpose of this study, they treated $r$-values larger than .30 (medium effect) and $R^{2}$ values larger than .13 (medium effect) as practically significant.

\section{Results}

Table 1 gives means, standard deviations and instrument reliabilities. Tables 2, 3 and 4 give the results of the standardised linear regression analyses for transformational leadership and the dependent variables of leadership acceptance, job satisfaction and job performance.

Table 2 shows linear regression analysis estimates for subordinate leadership acceptance, as a dependent variable, and the transformational leadership dimensions. Intellectual stimulation was the best predictor of leadership acceptance $(\beta=.18 ; p \leq .01)$ according to the public sector employees 
who participated in this study. Idealised influence and inspirational motivation $(\beta=.15 ; p \leq .01$ and $\beta=.11 ; p \leq .05)$ were also significant contributors (adjusted $R^{2}=.24$ ). They showed that the independent variable accounted for $24 \%$ of the variance in subordinate leadership acceptance.

Table 3 shows linear regression analysis estimates for job performance, as a dependent variable, and the transformational leadership dimensions. Idealised influence was the best predictor of job performance $(\beta=.31$; $p \leq$.001). Intellectual stimulation, individualised consideration and inspirational motivation $(\beta=.22 ; p \leq .01$; $\beta=.13 ; p \leq .001$; and $\beta=.12 ; p \leq .01$ ) were also significant contributors (adjusted $R^{2}=.60$ ). They show that the independent variable accounted for $60 \%$ of the variance in job performance.

Table 4 shows linear regression analysis estimates for job satisfaction, as a dependent variable, and the transformational leadership dimensions. Inspirational motivation was the best predictor of job satisfaction $(\beta=.41 ; p \leq .001)$. Idealised influence and intellectual stimulation $(\beta=.19 ; p \leq .001$ and $\beta=.16 ; p \leq .001$ ) were also significant contributors (adjusted $R^{2}=.62$ ). They show that the independent variable accounted for $62 \%$ of the variance in job satisfaction. In the light of these results, the researchers accepted their hypotheses.

\section{Discussion}

The purpose of this study was to investigate the relationship between transformational leadership and subordinate leadership acceptance, with job performance and job satisfaction as dependent variables.

The results of the study provide much-needed insight into the relationships between transformational leadership behaviours and employee attitudes and performance in the public service. The results also point to issues that the public service could address to root out the causes of poor service delivery, which results from incompetent management and leadership.

The results yielded significant correlations between transformational leadership and the dependent variables of leadership acceptance, job satisfaction and performance. With regard to transformational leadership (mean $=3.60$ ), intellectual stimulation appears to be the best predictor of subordinate leadership acceptance $(\beta=.18, p<.01$; mean $=3.38)$. Idealised influence $(\beta=15, p<01)$ and inspirational motivation $(\beta=12, p<05)$ are also significant contributors. The independent variable accounted for $24 \%$ of the variance in subordinate leadership acceptance (see Table 2).

Table 3 shows that idealised influence is the best predictor of job performance $(\beta=.31, p<.001$; mean $=3.69)$. Intellectual stimulation $(\beta=.22, p<.01)$, individualised consideration $(\beta=.13, p<.001)$ and inspirational motivation $(\beta=.12, p<.01)$ are also significant contributors. The independent variable accounted for $66 \%$ of the variance in job performance.
TABLE 1: Means, standard deviations and instrument reliabilities.

\begin{tabular}{llll}
\hline Variables & Mean & SD & $\boldsymbol{\alpha}$ \\
\hline Transformational leadership & 3.60 & .82 & .96 \\
Subordinate leadership acceptance & 3.38 & .68 & .71 \\
Job performance & 3.69 & .87 & .76 \\
Job satisfaction & 3.69 & .86 & .79
\end{tabular}

$\mathrm{SD}$, standard deviation; $\alpha$, Cronbach's Alpha reliability. $N=896$.

TABLE 2: Linear regression analysis estimates for transformational leadership dimensions and subordinate leadership acceptance.

\begin{tabular}{ll}
\hline Transformational leadership dimensions & Subordinate leadership acceptance \\
\hline Idealised influence & $.15^{* *}$ \\
Inspirational motivation & $.11^{*}$ \\
Intellectual stimulation & $.18^{* *}$ \\
Individualised consideration & -.02 \\
Adjusted $R^{2}$ & $.24^{* * *}$ \\
\hline
\end{tabular}

Standardised regression coefficients $\left(\beta^{\prime} \mathrm{s}\right)$.

${ }^{*}, p<.05 ;{ }^{* *}, p<.01 ;{ }^{* * *}, p<.001$

TABLE 3: Linear regression analysis estimates for transformational leadership dimensions and job performance.

\begin{tabular}{ll}
\hline Transformational leadership dimensions & Job performance \\
\hline Idealised influence & $.31^{* * *}$ \\
Inspirational motivation & $.12^{* *}$ \\
Intellectual stimulation & $.22^{* *}$ \\
Individualised consideration & $.13^{* * *}$ \\
Adjusted $R^{2}$ & $.60^{* * *}$ \\
\hline
\end{tabular}

Adjusted $R^{2}$

Standardised regression coefficients $\left(\beta^{\prime} \mathrm{s}\right)$

${ }^{* *}, p<0.01 ;{ }^{* * *}, p<0.001$

TABLE 4: Linear regression analysis estimates for transformational leadership dimensions and job satisfaction.

\begin{tabular}{ll}
\hline Transformational leadership dimensions & Job satisfaction \\
\hline Idealised influence & $.19^{* * *}$ \\
Inspirational motivation & $.41^{* * *}$ \\
Intellectual stimulation & $.16^{* * *}$ \\
Individualised consideration & .04 \\
Adjusted $R^{2}$ & $.62^{* * *}$ \\
\hline
\end{tabular}

Standardised regression coefficients $\left(\beta^{\prime} \mathrm{s}\right)$.

$* * *, p<0.001$

Table 4 also shows that, of the variables this study included, inspirational motivation is the best predictor of job satisfaction $(\beta=.41, p<.001$; mean $=3.69)$. Idealised influence $(\beta=.19$, $p<.001)$ and intellectual stimulation $(\beta=.16, p<.001)$ are also significant contributors. The independent variable accounted for $62 \%$ of the variance in job satisfaction. The amount of explained variance is unusually high.

In answering the research question of whether transformational leadership has a beneficial relationship with subordinate leadership acceptance, job performance and job satisfaction, this study shows that there is indeed a relationship between transformational leadership, subordinate leadership acceptance, job performance and job satisfaction.

However, uncertainty and change exerted downward pressure on the attitudes and performance of subordinates after elections. This resulted in negative outcomes, mostly at the provincial and municipal level. They include low 
employee morale, loss of key talent and poor service delivery. These results are consistent with findings that Medley and Larochelle (2005) reported. They found that transformational leadership relates most strongly to job satisfaction and job performance.

These results illuminate the vision for the future that transformational leaders need to create to persuade subordinates to perform optimally in a dynamic environment, even in the absence of clear and immediate goals (Nemanich \& Keller, 2007). In addition, in the uncertain context of leadership changes, subordinate job performance and satisfaction respond to the skills of transformational leaders in inspiring and motivating employees.

The findings support the expectation that transformational leaders increase employee acceptance as well as performance and satisfaction expectations. They try to transform the abilities, personal values and self-concepts of employees and move them to higher levels of needs and aspirations.

The present study showed that those responsible for leading departments do not have the appropriate transformational skills to manage their departments effectively and efficiently. This, in turn, has led to negative perceptions of employees about how leaders manage their departments and about their leadership. This has had a detrimental effect on the ability of employees to accept their new leaders and view the 'new organisation and its culture' positively.

Min-Huei (2005) supports the argument that leaders should consider using transformational leadership behaviours to motivate employees at all levels to make the extra effort ('organisational citizenship') that organisations need to maintain quality service delivery during change. Leaders should engage in transformational behaviours, like providing individualised attention to support employees during change and using their intellectual skills to help employees to understand the visions of organisations.

The public service departments that have transformational leaders at all levels from top to bottom convey to their staff, their customers, society as well as their suppliers and financial sponsors that:

- they have a vision for the future

- they are confident that they have leaders who are committed to developing their staff members and making the public services sector a success (Bass \& Avolio, 1994).

\section{Contribution to the literature}

This study makes an important contribution to our understanding of transformational leadership processes. The findings should encourage leaders to engage in transformational leadership behaviours in order to boost the creative performance of their employees or subordinates and to address the ever-increasing and continuously changing demands of the work environment and society.
Good leadership in the public sector is essential, particularly given the recent scandals about corruption and greediness. The findings add new knowledge that can improve public service practices for effective leadership, the retention of valuable staff members and quality service delivery.

Finally, the findings of this study might serve as a reference point for policy decisions about leadership change.

\section{Implications for future research}

This study showed that transformational leadership behaviour influences employees' performance, job satisfaction and acceptance of leadership. Given the lack of research on transformational leadership in South Africa, this study adds to the field of leadership studies by providing empirical research on this topic in the public sector.

Therefore, the study is significant in terms of understanding leadership and employee relationships as well as how organisations can improve these relationships. With regard to current research on transformational leadership in South Africa, this study suggests that transformational leaders could play a vital role in the public service.

This study addressed only three constructs of work-related behaviours (performance, job satisfaction and leadership acceptance). Further research in this field could examine other constructs related to the effectiveness and outcomes of public services. Examples of these constructs are organisational citizenship behaviour and employee commitment.

\section{Limitations of the study}

Although the current study yielded some interesting results, there are limitations that could limit its generalisability.

Firstly, the researchers drew their samples from provincial departments in head offices in each province. Secondly, the current findings may not apply to settings where employees are less educated or are not professionals. Lastly, relying simply on quantitative research does not allow for a complete understanding of complex leadership behaviour. It is important, for instance, to supplement quantitative research with qualitative research through in-depth case studies or face-to-face interviews with selected leaders or managers.

\section{Recommendations}

Transformational leadership requires an outlook that differs considerably from a mindset of compliance. Managers in the public sector should be experts on using the talents of employees in their departments to achieve provincial competitive advantage. Transformational leadership can play an important role in giving the leaders what they need in order to ensure success.

Leaders need to develop visions that all stakeholders share and should be able to use inspirational language to do so. Leaders must engage in acts that involve personal risk and sacrifice. In addition, socio-cultural and gender diversity 
require a strong vision in order to focus on mutual goals and provide a sense of assurance. Furthermore, to gain the trust of subordinates, leaders must be role models and show total commitment to achieving the objectives of the public service.

Leaders must commit the resources the public service needs to identify strategic objectives, outputs or results. They must ensure that the outputs, characteristics, work activities and tasks their subordinates perform are consistent with these objectives. According to Dubois, Rothwell, Stern and Kemp (2004), transformational leadership needs leaders who are willing to add a qualitative aspect to their quantitative mindset and who are open to rethink what they mean by performance and 'quality service delivery' - especially when the work is strategic to the success of the public service .

The national government will need to consider whether the leadership interventions that it has introduced to assist leadership at national, provincial and local level are having an effect on the broader change process that it has begun. More specifically, it is necessary to evaluate the interventions in terms of sustainability, cost and adding value.

\section{Conclusion}

Transformational leadership is vital to effective management because the effectiveness of leaders determines the success of organisations. According to Hall, Johnson, Wysocki and Kepner (2005), organisations that take the time to teach leadership are far ahead of their competitors. By becoming familiar with the transformational leadership approach and combining the four 'Is' (idealised influence, inspirational motivation, individualised consideration and intellectual stimulation), which Bass, 1998; Bass \& Avolio, 1993 modelled, managers can become effective leaders in the public service.

One can also use transformational leadership in one-onone or group situations. Using this approach, the manager (leader) and the associates (followers) become 'transformed' to improve job performance and help organisations to be more productive and successful.

The findings suggest that engaging in transformational leadership behaviours is an effective strategy to help line managers (both political and non-political) to meet challenges.

Finally:

when a leader is authentic and genuinely concerned about the wellbeing of his or her followers/subordinates and demonstrates an active commitment to the development of these subordinates, people are changed. (Whittington, Pitts, Kageler \& Goodwin, 2005, p. 602)

\section{Acknowledgements Competing interests}

The authors declare that they have no financial or personal relationship(s) that may have inappropriately influenced them when they wrote this paper.

\section{Authors' contributions}

M.M.M. (University of South Africa) designed the study, completed the data analysis and edited the article. P.M. (Tromso management consultant $\mathrm{cc}$ ) helped with the literature review and with distributing and collecting the questionnaires. M.M. (Tromso management consultant cc) funded the study.

\section{References}

Balogun, M.J. (2003). Leadership and Agency Governance: The search for the common cause of excellence in the African Public Service. Ethiopia: United Nations Economic Commission for Africa Addis Ababa.

Bass, B.M. (1985). Leadership and performance beyond expectations. New York: The Free Press.

Bass, B.M. (1990). Bass and Stogdill's Handbook of Leadership. New York: The Free Press.

Bass, B.M. (1990). From transactional to transformational leadership: Learning to share the vision. Organisational Dynamics, Winter, 114-178.

Bass, B.M. (1998). Transformational Leadership: Industrial, Military and Educational Impact. Mahwah, NJ: Lawrence Erlbaum Associates.

Bass, B.M., \& Avolio, B.J. (1994). Improving Organisational Effectiveness through Transformational Leadership. Sage: Thousand Oaks CA.

Bass, B.M., \& Avolio, B.J. (2000). MLQ Multifactor Leadership Questionnaire. Redwood City: Mind Garden.

Bass, B.M., Avolio, B.J., Jung, D.I., \& Berson, Y. (2003). Predicting unit performance by assessing transformational and transactional leadership. Journal of Applied Psychology, 88, 207-218. http://dx.doi.org/10.1037/0021-9010.88.2.207, PMid:12731705

Bono, J.E., \& Judge, T.A. (2003). Self-concordance at work: Toward understanding the motivational effects of transformational leaders. Academy of Management Journal, 46, 554-571. http://dx.doi.org/10.2307/30040649

Cohen, J. (1992). Quantitative methods in psychology: A power primer. Psychological Bulletin, 112(1), 153-159.

Covin, T.J., Kolenko, T.A., Sightler, K.W., \& Tudor, R.K. (1997). Leadership style and postacquisition satisfaction. Journal of Management Development, 16, 22-33. http:// dx.doi.org/10.1108/02621719710155454

Chemers, M.M. (2001). Leadership effectiveness: An integrative review. In M.A. Hogg \& S. Tindale (Eds.), Blackwell handbook of social psychology: Group processes, (pp. 376-399). Maulden, MA: Blackwell.

Drazin, R., Glynn, M., \& Kazanjian, R. (1999). Multilevel theorizing about creativity in organisations: A sensemaking perspective. Academy of Management Review, 24 286-307. http://dx.doi.org/10.2307/259083

Dubois, D.D., Rothwell, W.J., Stern, J.K., \& Kemp, K.K. (2004). Competency based: Human Resources Management. Palo Alto California: Davis Black Publishing.

Ernst, H., \& Vitt, J. (2000). The influence of corporate acquisitions on the behavior of key inventors. R \& D Management, 30, 105-119. http://dx.doi.org/10.1111/14679310.00162

Greenleaf, R. (2008). The Servant-Leader Within: A Transformative Path. New York: Paulist Press.

Groenewald, A., \& Ashfield, G. (2008, 07 May). When leaders are also explorers. The Star Workplace, p. 56.

Hall, J., Johnson, S., Wysocki, A., \& Kepner, K. (2005). Transformational leadership: the transformation of managers and associates. University of Florida, IFAS.

Harris, P.R., \& Moran, R.T. (2000). Managing Cultural Differences: Global Leadership Strategies for Cross-Cultural Business Success. Houston, TX: Gulf Publishing Company.

Haslam, S.A., \& Platow, M.J. (2001). Your wish is our command: the role of shared social identity in translating a leader's vision into followers' action. In M.A. Hogg \& D. Terry (Eds.), Social Identity Processes in Organisations, (pp. 213-228). New $\& D$. Terry (Eds.), Social
York: Psychology Press.

Hogg, M., \& Terry, D. (2000). Social identity and self-categorisation processes in organisational contexts. Academy of Management Review, 25, 121-140.

Hogg, M.A., \& Terry, D.J. (Eds.). (2001). Social Identity processes in organizational contexts, Philadelphia, PA: Psychology Press.

Hogg, M.A., \& Van Knippenberg, D. (2003). Social identity and leadership processes in groups. In M.P. Zanna (Ed.), Advances in Experimental Social Psychology, 35, 1-52. http://dx.doi.org/10.1016/S0065-2601(03)01001-3

Hogg, M. (1996). Social identity and self-categorization processes in organisational contexts. Academy of Management Review, 25, 121-140. http://dx.doi. org/10.2307/259266

House, R.J., \& Aditya, R.N. (1997). The social scientific study of leadership: Quo vadis? Journal of Management, 23, 409-473. http://dx.doi. org/10.1177/014920639702300306

Howell, J.M., \& Shamir, B. (2005). The role of followers in the charismatic leadership process: Relationships and their consequences. Academy of Management Review, 30, 96-112. http://dx.doi.org/10.5465/AMR.2005.15281435 
Ivancevich, J., \& Matteson, M. (2002). Organisational behaviour and management. (6th edn.). New York: McGraw-Hill.

Judge, T.A., Bono, J.E., Ilies, R., \& Gerhardt, M.W. (2002). Personality and leadership: A qualitative and quantitative review. Journal of Applied Psychology, 87(4), 765780. http://dx.doi.org/10.1037/0021-9010.87.4.765, PMid:12184579

Judge, T.A., \& Bono, J.E. (2000). Five-factor model of personality and transformational leadership. Journal of Applied Psychology, 85, 751-765. http://dx.doi. org/10.1037/0021-9010.85.5.751, PMid:11055147

Judge, T.A., \& Piccolo, R.F. (2004). Transformational and transactional leadership: A meta-analytic test of their relative validity. Journal of Applied Psychology, 89, 755768. http://dx.doi.org/10.1037/0021-9010.89.5.755, PMid:15506858

Jung, D.I., Chow, C., \& Wu, A. (2003). The role of transformational leadership in enhancing organisational innovation: Hypotheses and some preliminary findings. The Leadership Quarterly, 14, 525-544. http://dx.doi.org/10.1016/S10489843(03)00050-X

Kavanagh, M.H., \& Ashkanasy, N.M. (2006). The impact of leadership and change management strategy on organisational culture and individual acceptance of change during a merger. British Journal of Management, 17(1), 81-103. http:// dx.doi.org/10.1111/j.1467-8551.2006.00480.x

Keller, R.T. (2006). Transformational leadership, initiating structure, and substitutes for leadership: A longitudinal study of R\&D project team performance. Journal of Applied Psychology, 91, 202-210. http://dx.doi.org/10.1037/0021-9010.91.1.202, PMid:16435950

Koh, W.L., Steers, R.M., \& Terborg, J.R. (1995). The effects of transformational leadership on teacher attitudes and students performance in Singapore. Journal of Organisational Behaviour, 16, 319-333. http://dx.doi.org/10.1002/ job.4030160404

Leithwood, K.A., \& Jantzi, D. (2000). The effects of transformational leadership on organisational conditions and student engagement with schools Journal of Educational Administration, 38(2), 112-125. http://dx.doi. org/10.1108/09578230010320064

Lumley, E.J., Coetzee, M., Tladinyane, R., \& Ferreira, N. (2011). Exploring the job satisfaction and organisational commitment of employees in the information technology environment. Southern African Business Review, 15(1), 100-118.

Maitlis, S. (2005). The social processes of organisational sensemaking. Academy of Management Journal, 48, 21-49. http://dx.doi.org/10.5465/AMJ.2005.15993111

Marks, M.L., \& Mirvis, P.H. (1992). Rebuilding after the acquisition: Dealing with 'survivor sickness'. Organisational Dynamics, 21, 18-32. http://dx.doi. org/10.1016/0090-2616(92)90061-Q

Martins, N., \& Coetzee, M. (2007). Organisational culture, employee satisfaction, perceived leader emotional competency and personality type: an exploratory study in a South African engineering company. SA Journal of Human Resource Management/SA Tydskrif vir Menslikehulpbronbestuur, 5(2), 20-32.

Medley, F., \& Larochelle, D.R. (2005). Transformational leadership and job satisfaction. Nursing Management, 26(9), 68-68.

Michela, J.L., \& Burke, W.W. (2000). Organisational culture and climate in transformations for quality and innovation. In N.M. Ashkanasy, C.P.E. Wilderom \& M.F. Peterson (Eds.), Handbook of Organisational Culture and Climate, (pp. 117-129). London: Sage Publications Inc.

Min-Huei, C. (2005). A study to improve organisational citizenship behaviours. Academy of Management Journal, 15(7), 653-663.

Mokgolo, M.M. (2008). Management experiencing internal changes and external pressure. Management Today, 24(2), 52-55.

McKendall, M. (1993). The tyranny of change: Organizational development revisited. Journal of Business Ethics, 12, 93-104.

Nemanich, L.A., \& Keller, R.T. (2007). Transformational leadership in an acquisition A field study of employees. Leadership Quarterly, 18, 49-68. http://dx.doi. org/10.1016/j.leaqua.2006.11.003

Nygaard, A., \& Dahlstrom, R. (2002). Role stress and effectiveness in horizontal alliances. Journal of Marketing, 66(2), 61-82. http://dx.doi.org/10.1509/ jmkg.66.2.61.18474

Pillai, R., \& Meindl, J.R. (1998). Context and charisma: A 'meso' level examination of the relationship of organic structure, collectivism, and crises to charismatic leadership. Journal of Management, 24, 643-671. http://dx.doi. org/10.1177/014920639802400505
Rafferty, A., \& Griffin, M. (2004). Dimensions of transformational leadership: Conceptual and empirical extensions. Leadership Quarterly, 15, 329-354. http:// dx.doi.org/10.1016/j.leaqua.2004.02.009

Robbins, S. (1993). Organisational behaviour: Concepts, controversies, and applications. (6th edn.). New Jersey: Prentice Hall.

Robbins, S.P, Odendaal, A., \& Roodt, G. (2002). Organisational Behaviour: Global and Southern African Perspectives. Cape Town: Pearson Education South Africa.

Rothmann, S., \& Coetzer, E. (2002). The relationship between personality dimensions and job satisfaction. Business Dynamics, 11(1), 29-42.

Saari, L., \& Judge, T. (2004). Employee attitudes and job satisfaction. Human Resource Management, 43(4), 395-407. http://dx.doi.org/10.1002/hrm.20032

Sempane, M., Rieger, H., \& Roodt, G. (2002). Job satisfaction in relation to organisational culture. SA Journal of Industrial Psychology/SA Tydskrif vir Bedryfsielkunde, 28(2), 23-30.

Schepers, J.M. (1994). Die konstruksie en evaluering van ' $n$ prestasiebeoordelingsvraelys vir nie-akademiese personeel [The construction and evaluation of a performance evaluation questionnaire for non-academic personnel]. Johannesburg: RAU.

Shaughnessy, J.J., \& Zechmeister, E.B. (2003). Research methods in psychology. (4th edn.). New York: McGraw-Hill.

Shamir, B., House, R.J., \& Arthur, M.B. (1993). The motivational effects of charismatic leadership: A self-concept based theory. Organisation Science, 4, 577-594. http:// dx.doi.org/10.1287/orsc.4.4.577

Spector, P. (1997). Job satisfaction: application, assessment, causes and consequences. California: Sage Publication.

Van Dick, R. (2004). My job is my castle: Identification in orgnisational contexts. In C.L. Cooper \& I.T. Robertson (Eds.), International Review of Industrial and Organisation Psychology, 19, 171-203.

Van Knippenberg, D., \& Hogg, M.A. (2003). A social identity model of leadership effectiveness in organisations. In B. Staw \& R.M. Kramer (Eds.), Research in Organisational Behaviour, 25, 245-297.

Van Knippenberg, D., \& Van Leeuwen, E. (2001). Oganisational identity after a merger. In M.A. Hogg \& D.J. Terry (Eds.), Social identity processes in organisational contexts, (pp. 249-264). Philadelphia: Psychology Press.

Vera, D., \& Crossan, M. (2004). Strategic leadership and organisational learning Academy of Management Review, 29, 222-240. http://dx.doi.org/10.5465/ AMR.2004.12736080

United Nations Development Programme. (2003). Leadership and Socia Transformation in the Public Sector: Moving from Challenges to Solutions. New York: Oxford University Press.

Waldman, D., Javidan, M., \& Varella, P. (2004). Charismatic leadership at the strategic level: A new application of upper echelons theory. Leadership Quarterly, 15, 355380. http://dx.doi.org/10.1016/j.leaqua.2004.02.013

Waldman, D.A., Ramirez, G.G., House, R.J., \& Puranam, P. (2001). Does leadership matter? CEO leadership attributes and profitability under conditions of perceived environmental uncertainty. Academy of Management Journal, 44, 134-143. http://dx.doi.org/10.2307/3069341

Whittington, J.L., Pitts, T.M., Kageler, W.V., \& Goodwin, V.L. (2005). Legacy leadership: The leadership wisdom of the Apostle Paul. Leadership Quarterly, 16, 749-770. http://dx.doi.org/10.1016/j.leaqua.2005.07.006

Whittington, J., Goodwin, V., \& Murray, B. (2004). Transformational leadership, goal difficulty, and job design: Independent and interactive effects on employee outcomes. Leadership Quarterly, 15, 593-606. http://dx.doi.org/10.1016/j. leaqua.2004.07.001

Yukl, G. (2002). Leadership in Organisations. (5th edn.). Upper Saddle River, NJ: Prentice Hall.

Yukl, G., \& Howell, J.M. (1999). Howell, Organisational and contextual influences on the emergence and effectiveness of charismatic leadership. Leadership Quarterly, 10, 257-283. http://dx.doi.org/10.1016/S1048-9843(99)00014-4

Zammuto, F.R., London, M., \& Rowland, M.K. (1982). Organisation and rater differences in performance appraisals. Personnel Psychology, 35, 643-657. http:// dx.doi.org/10.1111/j.1744-6570.1982.tb02216.x 